\title{
HÄUFIGER VORKOMMENDE BEZEICHNUNGEN
}

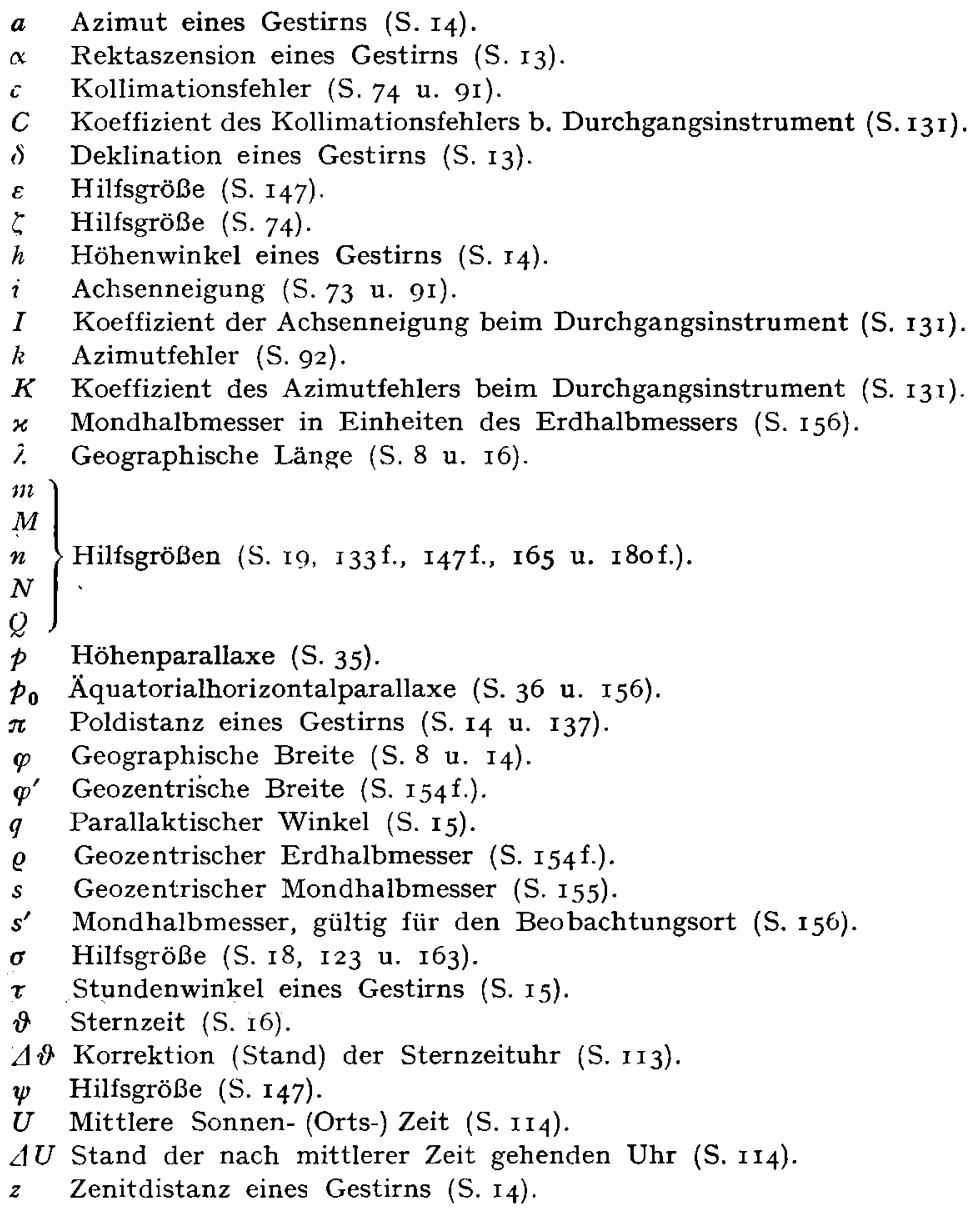

